\title{
Corpo, máscara e f(r)icção: a "fábula das três raças" no Buraco dos Capetas
}

\author{
John Cowart Dawsey ${ }^{1}$
}

Universidade de São Paulo, São Paulo, Brasil

E-mail: johndaws@usp.br 


\section{Resumo}

A encenação da "fábula das três raças" pode exigir uma máscara especial: cromática e caleidoscópica. Surreal. Como um espelho mágico, ela seria capaz de produzir surpreendentes transformações. Porém, o foco deste ensaio tem menos a ver com os poderes extraordinários de uma máscara do que com as suas relações com os corpos que por trás, por baixo ou por cima lampejam. Tais relações podem ser eletrizantes. Chegam a ser explosivas, como choque de chama de fósforo em pó de potássio. De repente, aflora uma imagem. Perigosa, ela relampeia com a força de uma revelação. Trata-se da fricção entre corpo e máscara, que, brincando e colocando um erre entre parênteses, prefiro chamar de f(r)icção. A seguir, pretendo captar o modo como irrompem imagens mineiras, ameríndias e afro-brasileiras em narrativas do Buraco dos Capetas, na periferia de uma cidade do interior paulista.

Palavras-chave: Corpo. Máscara. F(r)icção. "Fábula das três raças". Performance.

\section{Abstract}

The staging of the "fable of three races" may require a special type of mask: chromatic, caleidoscopic and surreal. Like a magic mirror, this mask would be capable of producing surprising transformations. However, rather than dwelling on the extraordinary powers of such a mask, this essay will focus on its relations with bodies which flash from behind, below or above. Such relations may be electrifying. Or explosive - like the shock of a flame of phosphorus on potassium powder. Dangerously, with the force of revelation, an image leaps forth. This is what happens with friction between body and mask, which I playfully call $f(r)$ iction, with the letter $R$ in parenthesis. In the following paper, an attempt is made to capture Afro-Brazilian, Amerindian and Mineiro images which erupt in narratives of Devils' Hole, on the edge of a city of the interior of the state of Sao Paulo.

Keywords: Body. Mask. F(r)iction. "Fable of three races". Performance.

ILHA

volume 11 - número 1 


\section{Uma máscara surreal}

To título de um dos livros de Frantz Fanon (2008), lampeja uma 1 imagem: pele negra, máscaras brancas. No Brasil, onde se conta a "fábula das três raças", também há máscaras que ganham densidade.

Caso fizéssemos uma encenação da "fábula das três raças", creio que precisaríamos de uma máscara especial. A personagem de Macunaíma, que, ao longo da narrativa de Mário Andrade, vai mudando de cor - do "preto retinto" ao "branco louro" -, poderia servir de modelo. ${ }^{2}$ Ao figurinista poderíamos propor a ideia de uma máscara feita de uma imensa variedade de cores, à moda de um caleidoscópio. Em três níveis apresentar-se-iam os fragmentos de espelhos. No primeiro e mais fundo, os estilhaços de materiais reluzentes em cores de pele indígena: vermelhas, amarelas e marrons. No segundo, os fragmentos em cores de espelhos africanos: café, cobre e grafite. O terceiro, um espetáculo em tons de branco e cor-de-rosa: os cacos de espelhos europeus. A própria máscara, em seu conjunto, poderia sugerir uma espécie de espelho mágico.

Seu segredo: o movimento de caleidoscópio, girando e produzindo as mais surpreendentes combinações. E incríveis transformações - até mesmo, em seu plano mais superficial, de negro virando branco. Enfim, uma máscara fantástica: surreal.

O que dizer da "fábula das três raças"? Nas interfaces da antropologia e do teatro, Richard Schechner (1985, p. 4) discute o modo como performers de diversas experiências rituais e tradições teatrais (tais como as dos rituais Yaqui e do teatro nô japonês) não procuram esconder o corpo por trás da máscara. A experiência de transformação vivida por performers e público tem muito a ver com uma relação 
entre máscaras e corpos capaz de produzir um estado liminar. Os momentos em que os corpos se revelam - ou irrompem - por trás, por baixo ou por cima de suas máscaras podem ser da ordem do extraordinário. Ou insólito.

A seguir, pretendo evocar alguns desses momentos, tais como lampejam em registros de cadernos de campo realizados nos anos 1980 em um lugar que vou chamar de Jardim das Flores, um pequeno abismo situado na periferia de Piracicaba. As pessoas que ali moravam também se referiam ao lugar como sendo o "Buraco dos Capetas". Conforme os registros que vêm a seguir, corpos friccionam as suas máscaras. E até mesmo - eu diria, brincando com a palavra e colocando o erre entre parênteses - corpos e máscaras se f(r)iccionam. Assim, despertam um modo subjuntivo ("como se") de situar-se em relação ao mundo, provocando fissuras, iluminando as dimensões de ficção do real e subvertendo os efeitos de realidade de um mundo visto no modo indicativo, não como paisagem movente, carregada de possibilidades, mas simplesmente como é. ${ }^{3}$

A fricção entre corpo e máscara - que sugiro chamar de f(r)icção - pode gerar alguns dos momentos mais eletrizantes de uma performance. A seguir, pretendo captar instantes dessa espécie explorando algumas imagens que irrompem em narrativas do Jardim das Flores. E se afundam numa cartilha.

\section{"Assim começou minha história..."}

Este ensaio tem uma história originária. Trata-se de uma tentativa de reler, muitos anos depois do primeiro contato com o texto, as elipses e as lacunas de uma cartilha rasurada que encontrei no Jardim das Flores, o Buraco dos Capetas. As origens do texto remontam a 1983, época em que eu fazia uma pesquisa nesse local. A cartilha pertencia ao filho de Anaoj e Mister Zé, ${ }^{4}$ casal do norte de Minas Gerais que, em companhia de conterrâneos e pessoas de outras regiões do Brasil, se mudou nos anos 1970 para Piracicaba, cidade do interior paulista. 
Era uma cartilha de catecismo, branca e cor-de-rosa, da qual constava apenas parte do texto: as páginas 13 a 32. Duas delas, em especial, chamaram a minha atenção:

Página 24, item 10. ASSIM COMEÇOU MINHA HISTÓRIA. [...] Deus, nosso Pai, quis dar-nos sua proteção, para começarmos bem a nossa história. Por isso fez-nos nascer dentro de uma família. [Há a imagem de uma família num carro. Um homem dirige. Uma mulher de óculos escuros está ao seu lado. No banco de trás aparecem dois meninos, cada qual numa das janelas, e uma menina no meio. Todos brancos. Ao fundo, um cenário com montanhas, uma lagoa, dois barcos à vela e um homem pescando.]

Página 32, item 14. NOSSA HISTÓRIA SE CONSTRÓI DIA A DIA. [...] Jesus nos ensinou que a gente não deve se preocupar nem com o futuro, nem com o passado, mas deve viver muito bem o presente [Imagem de uma menina branca usando um avental branco com uma fita cor-derosa no cabelo. Ao lado da menina, uma mesinha com réguas, esquadros e argila. Modelando a argila, a menina faz uma estatueta de um índio segurando um arco, sem flecha.] (26 de julho de 1983).

Um detalhe me surpreendeu: a imagem do índio e seu arco sem flecha. ${ }^{5}$

A menina devia ter, imagino, uns dez anos de idade. Era essa a idade do dono da cartilha, Abel, um dos seis filhos vivos de Anaoj e Mister Zé. A menina parecia estar numa escola. Abel também ia à escola. Anaoj o acordava de madrugada todos os dias da semana. Quando fazia mais frio, Abel relutava. Sua mãe era enfática: "Acorda, peste! Vai levar um tapa no ouvido se não levantar! Vai, vagabunda! Isso é hora de ficar dormindo?!" (20 de julho de 1983).

Por que o detalhe do índio teria me surpreendido? Seria porque, de algum modo, ele interrompia uma leitura que um aprendiz de antropólogo fazia de sua experiência no Buraco dos Capetas? Uma menina branca faz de argila a estatueta de um índio. No Jardim das Flores, as pessoas eram, em geral, mais da cor da argila do que da menina. Seus traços eram mais como os do índio. Também havia muitas pessoas negras, como Anaoj e Mister Zé. Em torno delas se

\section{ILHA}

volume 11 - número 1 
constituíam algumas das redes sociais de maior vitalidade no Jardim das Flores. Uma dessas redes acolhera o pesquisador, que nelas virou "João Branco". Ele também virou "João de Anaoj" e, tal como os brasileiros brancos sobre os quais lera nos escritos de Gilberto Freyre (1933), ganhou uma "mãe preta". Até que ponto esse pesquisador, movido por impulsos oriundos de estruturas mais fundas do pensamento e da emoção, procurava tornar-se "brasileiro"? Talvez ele também estivesse ali em busca de formas de recontar e tornar sua uma das histórias mais recorrentes do imaginário brasileiro e, ao mesmo tempo, mais intrigantes para estrangeiros americanos e europeus: a "fábula das três raças". ${ }^{6}$

No entanto, as páginas da cartilha que eu tinha em mãos apresentavam apenas imagens de uma família branca. O índio aparecia sob a forma de estatueta. E não havia negros. Tudo isso era óbvio. Supondo, porém, que a família branca ali representada era uma família brasileira, talvez um elemento menos óbvio se insinue, pela ausência, no texto. Afinal, era uma cartilha da Igreja Católica. Nesse caso, não era de se esperar que, em meio às páginas ausentes, se encontrasse uma imagem de São Benedito ou, ao menos, de Nossa Senhora Aparecida, a Padroeira do Brasil, de cor escura, senão negra? Até mesmo (ou principalmente?) entre pessoas brancas no Brasil, traços associados às manifestações dos negros surgem com força na configuração dos símbolos nacionais. Esse fenômeno pode ser constatado em relação não apenas à Aparecida, mas também ao samba, à feijoada, a Pelé. De modo semelhante, traços indígenas irrompem em diversos eventos expressivos: Círio de Nazaré, boi-bumbá de Parintins, caboclinhos em Festa de Catopês etc. As vanguardas antropofágicas do modernismo brasileiro há tempo nos disseram: tupi or not tupi. Invocaram ancestrais indígenas e a primeira língua geral do Brasil. Símbolos recriam-se com base em elementos que vêm como se fossem dos subterrâneos de um povo ou nação. Na página 32 da cartilha, via-se uma pálida lembrança desse processo: uma menina branca faz de argila a estatueta de um índio.

Na página 24, a família anda de carro em meio a uma paisagem idílica: montanhas, lagoa, barcos etc. O Jardim das Flores, onde a 
cartilha havia sido encontrada, constituía, apesar do nome, um dos locais menos idílicos na paisagem de Piracicaba. ${ }^{7}$ Os próprios moradores chamavam-no de Buraco dos Capetas. O detalhe: a cartilha foi encontrada sobre um saco de cimento, ao lado de uma fossa aberta, cheirando a enxofre e podridão, num banheirinho que ficava ao lado de uma valeta em frente ao barraco de Anaoj.

A maioria dos moradores viera de Minas Gerais, um estado montanhoso. Um número expressivo deles era oriundo das regiões de Montes Claros, Porterinha e Novo Cruzeiro. Foram para Piracicaba na época em que se deu a construção da Caterpillar e do segundo distrito industrial. Assim que terminaram as obras, "caíram no buraco". Também "caíram na cana". Viraram "boias-frias". Na época, ninguém ali era dono de carro. Por outro lado, os "boias-frias" produziam a matéria-prima da qual se fazia combustível. Esse impulsionava a indústria automobilística e alimentava imagens de desejo de uma sociedade, tal como a que se encontrava na cartilha.

Em Piracicaba, nos anos 1980, ainda se vivia sob o embalo de sonhos de progresso, movidos, em razão dos programas do Proálcool e do Planalsucar, por uma visão do despertar de um gigante adormecido. Na cana-de-açúcar encontrava-se um substituto do petróleo dos xeiques das arábias, cujo embargo havia, nos anos 1970, interrompido abruptamente o chamado "milagre econômico". Se os programas do Proálcool e do Planalsucar pretendiam fazer despertar um gigante adormecido, a sensação de quem morava no Jardim das Flores era de quem havia caído num buraco. Em meio a um clima de embriaguez, suscitado pelo que Walter Benjamin chamaria de "narcótico do progresso", às vezes irrompiam visões do paraíso. Mas a sensação de quem morava no buraco era outra.

Anaoj: Depois que meu povo caiu aqui nesse buraco, não conseguiu levantar mais. Por isso, estamos nessa desgraça. E meu povo é atentado demais! (21 de fevereiro de 1984).

Anaoj: Ai, nossa mãe do céu...

Lrds: Cair nesse buraco e morar no inferno é a mesma coisa (13 de agosto de 1983). 
Muitos mineiros "caíram no buraco". Mas o Jardim das Flores não apresenta apenas uma imagem de Minas. Ali, numa área de 27 mil $\mathrm{m}^{2}$, nessa fenda na terra - uma grota ou pequena cratera localizada na periferia de Piracicaba - encontrava-se, em forma de um mosaico carregado de tensões, uma imagem do Brasil. A maioria era de Minas, norte de Minas. Havia também cearenses, sergipanos, baianos, paranaenses, paraibanos, piauienses, pernambucanos - e paulistas. Havia inclusive piracicabanos, alguns com origens nos estratos do "antigo Risca-Faca" sobre os quais a favela se ergueu.

Não obstante, a imagem de Minas era poderosa. Ela ganhava proporções cósmicas. Outras regiões do universo agrupavam-se ao seu redor, como se entrassem em sua órbita.

Manoel quis saber de onde eu era. Quando lhe falei que eu havia nascido no Brasil, mas de família que viera dos Estados Unidos, ele disse: "Olha, eu vou mostrar pra você". Apanhando um pedaço de pau, ele desenhou um círculo imenso no chão de terra do barraco. "Isso aqui é Minas Gerais", explicou. Às margens do grande círculo mineiro, ele fez vários círculos minúsculos: São Paulo, Paraná, Mato Grosso, Bahia... e, o menor de todos, Estados Unidos (8 de julho de 1983).

Falava-se de "nação" mineira. No mapa do mundo de Manoel, Minas parecia englobar outros lugares. Até virava uma imagem do Brasil. Era centro. Coração e corpo do Brasil. Umbigo do mundo. Às vezes o pesquisador não sabia ao certo se era Minas que ficava no Brasil ou se, ao contrário, o Brasil cabia em Minas. A história de que mineiros "caíram no buraco", na periferia de uma cidade do interior paulista, evocava um acontecimento insólito. Era como se o universo houvesse sido tragado por suas próprias margens. As coisas estavam invertidas. Os mineiros, afinal, caíram num "buraco" na periferia de uma cidade do interior paulista. Viam-se às margens das margens das margens. Minas Gerais virou também uma alegoria do Brasil.

Neste texto, tenho interesse em explorar dimensões de um sentimento que lampeja no Jardim das Flores, numa imagem de susto. Ver-se ou descobrir-se como brasileiro pode suscitar uma experiência de espanto. Trata-se de uma experiência de profundo 
estranhamento de um brasileiro no Brasil, vendo-se sendo visto pelo outro como figura estranha. E isso, num momento, que não deixa de evocar um tempo de longa duração, no qual estrangeiros parecem estar tomando conta do país.

Ao atravessar a rua Moraes Barros na curva ao lado da Praça José Bonifácio, um bêbado com mochila de peão nas costas vira o corpo num gesto gracioso e pára por um instante em meio ao trânsito: "Vocês passam por mim que nem o vento! Estão pensando que sou estrangeiro?! Os estrangeiros estão tomando conta [...]. Eu sou daqui, mas vou pra Bahia!" (12 de agosto de 1983).

Mineiros e pessoas vindas de outras partes do Brasil haviam construído o segundo parque industrial de Piracicaba nos anos 1970. Algumas multinacionais, com destaque para a Caterpillar, formavam o núcleo do novo parque, que desbancava o antigo. Os relatos de pessoas do Jardim das Flores são recorrentes a esse respeito:

Aqui, foi assim: nós fizemos a Caterpillar e, depois, caiu tudo na cana (30 de maio de 1984).

A gente trabalha pra construir as indústrias [...]; quando fica tudo pronto, é só estrangeiro, japonês, americano, que vai trabalhar. Os brasileiros eles mandam embora. Os brasileiros que ficam é só pra fazer faxina ou limpar peça de máquina (30 de maio de 1984).

Trata-se de uma experiência insólita de quem se encontra como figura estranha em sua própria terra, às margens de histórias que ali se contam. Evoca-se uma sensibilidade. O que dizer dessa experiência? Como pensá-la em relação à "fábula das três raças"?

\section{A "fábula das três raças"}

O script é conhecido. Nos anos 1500, brancos portugueses descobriram o Brasil. Estabeleceram uma colônia em meio aos povos indígenas. A despeito das cartilhas de padres jesuítas, esses povos eram arredios. Logo chegaram, em navios negreiros, escravos africanos para trabalhar. Havendo poucas mulheres brancas, muitas

\section{ILHA}

volume 11 - número 1 
mulheres negras e indígenas viraram mães dos filhos de portugueses. O povo brasileiro surgiu da mistura dessas três raças.

O adendo também é importante. Em inícios dos anos 1800, ainda havia poucos brancos no Brasil. Isso logo mudaria. Ao longo do século, chegam levas de imigrantes europeus. O próprio rosto do Brasil se transforma. Em meio a sonhos de progresso e à mistura das raças, observa-se o branqueamento da nação.

Em tons idílicos, a "fábula das três raças" não deixa de evocar a vocação do brasileiro para a mistura entre povos. A aquarela brasileira é cantada em verso, em tons musicais que sugerem harmonias de raças e cores. No concerto das nações, o Brasil já figurou como lugar de "democracia racial" e de um progresso sem traumas.

Como já foi sugerido, a encenação da "fábula das três raças" pode exigir uma máscara especial: cromática e caleidoscópica. Surreal. Como um espelho mágico, ela seria capaz de produzir surpreendentes transformações.

Porém, o foco deste ensaio tem menos a ver com os poderes extraordinários de uma máscara do que com as suas relações com os corpos que por trás, por baixo ou por cima lampejam. Tais relações podem ser eletrizantes. Chegam a ser explosivas, como choque de chama de fósforo em pó de potássio. De repente, aflora uma imagem. Perigosa, ela relampeia com a força de uma revelação. Trata-se da $\mathrm{f}(\mathrm{r})$ icção entre corpo e máscara, como dito, com o erre entre parênteses.

A seguir, pretendo captar o modo como irrompem imagens mineiras, ameríndias e afro-brasileiras em narrativas do Buraco dos Capetas. Encontramos algumas delas em elipses da cartilha discutida no início deste artigo.

\section{Imagens mineiras}

Seria a "fábula das três raças" uma metanarrativa do Brasil, uma matriz da qual surgem histórias do que veio a ser? Nas histórias que se contam no Jardim das Flores e que evocam, inclusive, travessias do sertão mineiro e de outros sertões, o olhar volta-se com atenção para os redemoinhos, os refluxos e as contracorrentes. Ou, simples- 
mente, para histórias que submergiram ou não vieram a ser. A linguagem, em pedaços, não deixa de evocar uma espécie de paisagem:

Débora: Eles iam quebrar açude... o Dops... o rio secava. [...] O povo vivia de horta. Mas, agora está tudo morrendo. Pra pobre não tem mais terra não. Os fazendeiros estão com a terra. Eles não deixam abrir picada. O sondador fica na árvore. Ele mata! Lá diz assim: "Matou um e o outro está no pau" (23 de agosto de 1983).

Anaoj: A Débora é doida toda vida. Em Minas, ela amarrava um barbante num pau e saía assim... andando pra longe, dizendo que estava medindo a terra (19 de julho de 1983).

A justaposição de anotações em cadernos de campo redigidos no Jardim das Flores produz imagens e montagens carregadas de tensões. Ali se reúnem pedaços e fragmentos residuais de erosão social em relações surpreendentes, inusitadas. "Moisés segue caminho para o seu barraco, rindo e bradando, 'O buraco é nosso, não é? Vou dar uns tiros!'" (6 de julho de 1983).

Imagens do passado articulam-se ao presente, fazendo irromper forças suprimidas em meio a uma paisagem. O Jardim das Flores apresenta-se como a realização de sonhos em forma de paródia: "O buraco é nosso, não é?".

Nesse cenário, a erupção de imagens mineiras pode ter menos a ver com a produção de estados de nostalgia do que de inervações corporais. Abaixo, cadernos de campo evocam uma série de quatro lembranças de Anaoj, seguidas de seu epílogo.

Em Minas Gerais, Anaoje Mister Zé moravam com a família de um fazendeiro, um tipo alegre e brincalhão. O seu nome era Leonel. Com o passar do tempo, porém, Anaoj ficou desgostosa. Sobrecarregada, ela cozinhava, lavava roupa e fazia a limpeza para as duas famílias.

Certo dia, antes de sua saída da casa, Anaoj enfrentou Leonel: "Sou preta, ó, mas não sou empregada de você e sua família!" (31 de abril de 1984).

Leonel chegou para Mister Zé, falando: "Hoje é dia de trabalhar, não é dia de bestar!".

Mister Zé explodiu: "Bestar?! Eu trabalho a vida, a semana inteira pra vocêficar bestando feito uma vagabunda! Eu bestar?!

\section{ILHA}

volume 11 - número 1 
Sou preto, mas não sou escravo pra ficar te sustentando! (31 de abril de 1984).

Na tentativa de convencer Mister Zé e Anaoj de não irem embora, Leonel ofereceu dinheiro. Mister Zé reagiu: "Fica de gorjeta pra você! Toma o meu suor pra você comer no caminho dos infernos!" (31 de abril de 1984).

Quando Anaoj e Mister Zé voltaram para Minas, Leonel queria que eles trabalhassem de novo para ele. Mas Anaoj lhe disse: "Já trabalhamos pra encher sua barriga uma vez. Duas vezes não!" (31 de abril de 1984).

"Ele matou muitos. Pra eles não tem lei. Punha pra trabalhar, depois matava. Peão sumia" (31 de abril de 1984).

O que havia suscitado o retorno dessas lembranças? Imagens como essas, que evocavam a fúria de Mister Zé e Anaoj diante de situações que eles associavam à "escravidão", compunham um acervo de lembranças recorrentes. Elas não deixavam de apresentar afinidades eletivas com outras, de estratos mais recentes, referentes a experiências vividas no Buraco dos Capetas:

Anaoj está em pé de guerra. Mister Zé tem trabalhado sem contrato, como sempre, numa construção. Finalmente, recebeu o pagamento por dezoito dias de trabalho. Ficou aborrecido. Não quis nem pegar o dinheiro, mas pegou. Anaoj não aceitou. Foi devolver.

Anaoj: "Falei: 'Vocês acertam depois com o Mister Zé. Nem precisa falar que eu trouxe. Vinte mil! Ele virou moleque agora?! Isso não é papel de homem!' João, Abel ganhou dez mil em duas semanas, e ele é moleque! Voltei e disse: 'Mister Zé, você vai lá e tira sangue se precisar!"” (4 de fevereiro de 1984).

O que fez com que Anaoj devolvesse o dinheiro? Teriam sido a lembrança do gesto de Mister Zé diante de Leonel e as esperanças ainda não realizadas contidas naquele gesto?

Algumas das imagens que lampejam nessas lembranças revitalizam esperanças que correm riscos de adormecer ou amortecer em corpos que caíram num "buraco" na beira de uma cidade do interior paulista. Ao contar histórias sobre elas para si mesmas, as pessoas do Jardim das Flores também contavam histórias que ainda não vieram a ser. 


\section{Imagens afro-brasileiras}

No Jardim das Flores, também irrompiam imagens de deslocamentos primordiais e travessias ainda mais distantes, no tempo e no espaço, do que as do sertão mineiro. Nessa grota e nos seus arredores, às vezes apresentava-se uma imagem da África.

Esperando por meu ônibus, em frente ao bar do Risadinha, vejo uma pessoa no meio da rua. Trata-se de um homem negro, esguio e bêbado, com uma mochila de peão nas costas. De cabeça erguida, olhando para o alto, ele canta para as estrelas. Em meio à escuridão, uma pequena lâmpada brilha em frente ao bar. O peão parece alheio ao movimento das outras pessoas que, também de mochilas nas costas, passam ao lado, voltando do serviço, descendo morro abaixo e desaparecendo nos barracos. As palavras do cantador brotam como os disparos de uma arma. Capto apenas alguns dos fragmentos: "Não tenho pai nem mãe/ Sou neto de africano/Sai da frente senão eu atiro/Sou homem sem rumo/Não tenho onde dormir...".

O ônibus chega em velocidade, trôpego e barulhento, balançando de um lado para o outro ao dobrar a esquina. Ainda faz estrondo, com ruidos do freio, parando de repente, no susto, rente ao bêbado no meio da rua.

O motorista grita: "Sai da frente, pinguço, que já matei um hoje!".

De fato, conforme as notícias que se espalharam no bairro, um rapaz havia sido atropelado pelo onibus nesse dia (14 de maio de 1985).

Numa das passagens mais belas da literatura antropológica, um pigmeu do Congo, cujo nome era Kenge, sem saber da presença do pesquisador, canta no meio da noite, olhando para o alto e dançando sozinho com a lua e a floresta. Kenge dança após haver visto as "vilas-modelo" destinadas aos trabalhadores de plantations. Nas "vilasmodelo" não havia árvores. De volta à floresta, Kenge recompõe as suas relações com o cosmos por meio do canto e da dança. ${ }^{8}$

O peão que encontrei numa das ruas beirando o "buraco" do Jardim das Flores canta para as estrelas. E evoca o continente africano ("sou neto de africano"). Uma cidade é a sua floresta. Mas a sua dança não recompõe o cosmos. O lugar onde ele se encontra não the

\section{ILHA}

volume 11 - número 1 
permite reconstituir uma floresta dos símbolos, apenas os seus restos e subterrâneos. O seu canto tem o sopro de coisa ruidosa. Não se sabe quem está mais embriagado, o peão ou o ônibus. O ônibus da cidade também anda de jeito trôpego. Fazendo barulho e encenando a sua dança de bêbado, o peão entra em relação de mimese com uma cidade. Na interrupção da cena, aos ruídos de um freio e sob o brilho da pequena lâmpada de um bar, anuncia-se um desastre. Nessa floresta há cheiro de cinza. É de cana queimada, dos arredores da cidade. E de árvores desaparecidas. Esse peão também é um "boia-fria". Aqui também relampeia uma imagem de sertão mineiro. "Diolinda, rindo, xinga Anaoj: 'toco de sicupira!' 'toco de braúna!'” (25 de maio de 1983).

"toco de sicupira!" e "toco de braúna!" são os restos de árvores grandes das matas de Minas Gerais que ficam após as queimadas.

Deslocado, o bêbado canta à beira de um pequeno abismo. "Não tenho pai nem mãe/Sou neto de africano". Ele sai do Buraco dos Capetas. Vem das entranhas e dos fundos do Brasil. De sertões. No meio da rua lampeja uma imagem. O distante se faz próximo. O familiar vira estranho. Mas não há rito de passagem: o estado liminar é de longa duração. De buracos irrompem brasileiros de travessias - estrangeiros em sua própria terra. O espantoso é coisa do cotidiano.

Nessa beira havia um lugar onde a imagem da África se materializava com muita força: o barraco do "Saravá":

Surpreendo-me com a beleza do interior. Olhando desde o lado de fora, trata-se de um barraco como outro qualquer, feito de tábuas velhas e remendadas, e de cor acinzentada. (O cômodo de "João Branco" - o meu - destoa dos vizinhos por haver sido caiado.) No interior do "Saravá", me deparo com uma explosão de cores, imagens, estatuetas, e retratos nas paredes. Bandeirinhas multicoloridas atravessam o espaço. Sente-se o cheiro de velas. E da fumaça de um charuto pendurado da boca de uma mulher. Passando de mão em mão circulam cuias de coco com pinga. Ao som do atabaque moças giram balançando braceletes e colares. Vestidos brancos tocam os calcanhares, roçando o chão. Nos cantos, a tudo assistindo, se encontram santos, orixás, caciques, caboclos... Vejo uma Iara luminosa, e São Jorge lutando contra o dragão (17 de junho de 1983).

ILHA

volume 11 - número 1 
Alguns dos tiros que diariamente interrompiam o cotidiano dos moradores do Jardim das Flores saíam desse barraco. Ali morava Pedro, que, devido à fama de inventor, ganhou o apelido de "Professor Pardal". Pedro era um "fazedor de espingarda". A seguir, o seu relato:

Eu passo o dia assim, sentado nessa cadeira... os números multiplicando, multiplicando na minha cabeça, e a minha cabeça fervilhando... Aí, eu levanto, vou lá fora e "pê!". Dou um tiro. Sento de novo na cadeira... os números multiplicando, multiplicando na minha cabeça, e minha cabeça fervilhando... Vou lá fora e "pê!". Dou um tiro. Sento de novo na cadeira... Até que um dia fico doido, vou lá fora e grito. Todo mundo acha que fiquei louco. Mas, é aí que eu vou inventar alguma coisa! Eles me chamam de Professor Pardal. A minha vida é isso aí. Fico matutando, ponho uns discos pra ouvir, e dou tiro (17 de junho de 1983).

Quais eram esses discos?

Após alguma insistência de Pagé, Professor Pardal busca no quarto alguns discos. Já passou da meia-noite. Reconheço os de Roberto Carlos e Paulo Sérgio. São discos antigos. Num deles vejo escrito, "pais de santo". Pergunto que tipo de disco éesse. Pedro: "Esse disco você não entende. É tudo em africano. Aí tem cada história... Se você entender, dói o coração".

Ele colocou o disco na vitrola para tocar. Pedro escutava, depois traduzia algumas palavras: "okurí quer dizer homem, (?) quer dizer mulher".

Perguntei como ele aprendeu essas coisas. Ele me disse que tem um livro que explica o significado de todas as palavras africanas. Ele se interessou pelo candomblé quando morava em São Paulo, num parque de diversões (17 de junho de 1983).

Uma "tradição" africana aqui aparece como um acervo de fragmentos e estilhaços a serem decifrados. Nos discos de "pais de santo", Pedro encontrava os vocábulos de uma tradição, mas não a sua gramática. Aos ouvidos de um "Professor Pardal", porém, os vocábulos se abriam para os usos inventivos da história. Suscitavam estados de inervação corporal.

\section{ILHA}




\section{Imagens ameríndias}

Embora com menos frequência, imagens ameríndias também irrompiam em notas de cadernos de campo feitas no Jardim das Flores. Um dos incidentes envolve Diolinda, uma amiga de Anaoj. O relato revela a força de explosão com que essas imagens eram capazes de emergir. Diolinda era uma viúva do sul da Bahia que residiu no norte de Minas antes de seguir para Piracicaba. Morava num cômodo encostado ao barraco de seu irmão, Dijalma. Esse, que também era viúvo, havia se juntado recentemente com outra mulher. Diolinda sentia a presença dessa mulher como uma ameaça. Por causa dela, Diolinda corria o risco de ficar sem o apoio do irmão e das redes que lhe protegiam. Certo dia, após uma "disputa com a capeta", Diolinda passou pelo barraco de Anaoj. Tomando café, ela disse:

Sou mulher de destino. Aquela capeta quis me endoidar, mas não tem nada não. Também sou capeta. Sou filha de índia que laçaram no mato. Minha mãe era índia, india brava que não tinha medo dos homens. Enfrentava qualquer arma ou nação. Só canhão pra derrubar aquela índia do mato! E meu pai até jagunço foi. Era baiano, sabia lidar com tudo que era arma, carabina, garrucha, Mausa, M-14... Já nasci capeta, uma diabinha. Por isso, não tenho medo dos capetas. Pode vir quantos quiserem que vamos nós explodir no meio dos infernos. Enfrento os diabos e expulso tudo de lá. Tenho fé. Deus está comigo! Solto tudo de lá! (25 de maio de 1983).

Imagens relegadas ao lixo da história ressurgem carregadas de força originária, energizadas inclusive pelo sinal negativo com o qual foram conferidas pela "tradição". Num relato sobre Aparecida, a "primeira mulher de Dijalma" (a que morreu) lampeja outra imagem indígena:

Vizinhos ameaçavam dar uma surra na criança por causa de uma pedra "perdida". "Aparecida pulou no meio da aldeia que nem uma doida." "Pode vir!", ela esbravejou, "que eu mato o primeiro que vier!". Com efeitos de pasmo, Aparecida do "buraco dos capetas" protegera o seu filho da raiva dos homens. "Aquilo que era mulher!", sua cunhada me disse. "Enfrentava qualquer capeta!" (7 de junho de 1983).

ILHA

volume 11 - número 1 
Imagens do passado articulam-se ao presente em momentos de perigo.

Os restos de uma história incorporada, latentes, encontram na superfície dos corpos os sinais diacríticos capazes de provocar não apenas os gestos de diferenciação, mas também impulsos da rememoração:

Diolinda fala de Anaoj: "Eu gosto dessa preta. Pra mim essa preta é loura!" [...] "Eu sou loura, Anaoj". Anaoj brinca: "Você é irmã de João Branco?". Ela ri. Diolinda pega o seu próprio cabelo para mostrar. Ela diz que seu cabelo não é como o de Anaoj, mas é como o de sua mãe que era índia. Ela se lembra da mãe penteando o cabelo que descia até o chão (25 de agosto de 1983).

Essas imagens não deixam de evocar alguns dos fios que tecem a "fábula das três raças" e a máscara do branqueamento: "Pra mim essa preta é loura!". No entanto, nessas lembranças de uma "mãe penteando o cabelo que descia até o chão" se encontram outros fios, também, capazes de provocar o estremecimento de corpos e máscaras ( Seriam capazes, imagino, de acender e dar movência até mesmo a uma estatueta de índio.).

\section{Despertando a Bela Adormecida}

Neste estudo, imaginei como se poderia contar a "fábula das três raças" num palco com uma máscara. Talvez o aspecto mais interessante das máscaras, como mostrou Marcel Mauss (2003), seja a sua capacidade de nos transformar em pessoas. No exercício de imaginar uma encenação da "fábula das três raças", deparamo-nos com uma máscara extraordinária, de natureza caleidoscópica e capaz de expressar uma imensa variedade de formas e cores. E de transformar algumas cores em outras. "Pra mim essa preta é loura!" Seria a máscara de tantas cores também uma máscara do branqueamento?

De acordo com Mikhail Bakhtin (1993), as máscaras revelam a alegre transformação e relatividade das coisas. Talvez o elemento mais interessante e menos óbvio da concepção de Bakhtin seja que as próprias máscaras também se transformam. Às vezes se desfiguram. Em 
momentos de $\mathrm{f}(\mathrm{r})$ icção, que chegam a ser explosivos, revelam-se a movência e a inervação de corpos e máscaras.

Como já foi dito, esta pesquisa aconteceu num momento em que se sonhava muito com um Brasil gigante. Por meio de programas como o Proálcool e o Planalsucar, esperava-se despertar um gigante adormecido em berço esplêndido. Em tal cenário, os "boiasfrias" irromperam substituindo xeiques árabes.

Há sonhos de despertar assim como há o despertar dos sonhos. Um gigante escuro adormecido esfregando os olhos vira branco? Um sonho de despertar. Mas, no despertar do sonho, com efeitos de choque, não haveria também um branco descobrindo-se em outras cores? Sonhos cromáticos. Por que uma máscara de branqueamento? Em giros e contragiros de caleidoscópios não se produziriam dos cacos de espelhos mágicos inúmeras configurações, fazendo dos fundos aflorar estilhaços reluzentes nas cores vermelhas, amarelas e marrons e fragmentos espelhados nas cores fortes do café, cobre e grafite?

O que dizer dos sonhos de João Branco, que encontrou no Buraco dos Capetas uma espécie de "mãe preta"? Ao voltar do canavial, ele parecia gostar das reações que provocava na vizinhança. E gostou especialmente do susto fingido de um dos vizinhos, que vendo o seu corpo coberto de cinzas de cana queimada, às gargalhadas, exclamou: "Eu sabia que você era loiro, mas que você era preto eu não sabia!" (27 de setembro de 1983). Teria sido o próprio pesquisador seduzido pela possibilidade de ser outro? E, assim, de alguma forma, descobrir-se a si mesmo? Nos sonhos mais fundos que se agitam no giro ou contragiro de um caleidoscópio, não encontraríamos as imagens mais reveladoras de Macunaíma transformando-se em direção inversa - como branco virando índio, black ou negão? E, nesse movimento, uma das experiências mais fundas de virar brasileiro? Tupi or not tupi, tutu or not tutu?

Sonhos de gigantes adormecidos? A experiência de quem havia “caído no Buraco dos Capetas" estava mais próxima de amortecimento do que de adormecimento. No imaginário do lugar, com as energias explosivas da experiência de quem vivia no "buraco", a morte ron- 
dava. E os moradores se divertiam chamando-se uns aos outros de "assombrações" e "espantalhos". Ao passo que uma imagem de corpo sem alma manifesta-se na figura do espantalho, a imagem inversa, de alma sem corpo, lampeja numa assombração. Espanto cotidiano.

O que acontece quando uma máscara deixa de despertar a alma de um corpo? Uma máscara pode fazer um corpo sonhar? Também há sonhos que produzem esquecimento, inclusive do próprio corpo. Em casos como esses, a f(r)icção entre corpos e máscaras poderia suscitar o choque necessário para fazer despertar?

Amontoam-se questões. No fundo, o corpo que $\mathrm{f}(\mathrm{r})$ icciona uma máscara também não seria feito de máscaras que viraram corpo? Em momentos de $\mathrm{f}(\mathrm{r})$ icção, um corpo poderia despertar para os seus sonhos esquecidos ou mais profundos? Como sonhos dentro de sonhos, caleidoscópios giram em direções contrárias. Às vezes os caleidoscópios precisam ser despedaçados.

Como fazer despertar? Em um de seus estudos, Robert Darnton (1988) surpreende os leitores ao apresentar "estranhas" versões de "contos de fada", vestígios de uma cultura oral de camponeses do século XVIII na França. Walter Benjamin também se interessou por contos de fada. Em correspondência ao seu amigo Gershom Scholem, ele revela o prefácio que teria escrito para uma possível reapresentação do seu trabalho rejeitado para a Universidade de Frankfurt: A origem do drama barroco alemão (Benjamin, 1992). Ele desistiria do plano. Mas o prefácio, que ele contava entre seus melhores escritos, diz o seguinte:

Eu gostaria de recontar a história da Bela Adormecida.

Ela dormia em meio aos arbustos de espinhos. E, após tantos e tantos anos, ela acordou.

Mas não com o beijo de um príncipe feliz.

O cozinheiro a acordou quando deu na jovem cozinheira um tabefe nos ouvidos que ressoou pelo castelo, zunindo com a energia represada de tantos anos.

Uma linda criança dorme atrás da cerca viva espinhosa das páginas que seguem. 
Mas não deixem que qualquer príncipe de fortuna trajado no equipamento deslumbrante do conhecimento chegue perto. Pois no momento do beijo de núpcias, ela pode lhe morder [...] (Benjamin apud Buck-Morss, 1991, p. 22).

A versão benjaminiana da Bela Adormecida evoca o espírito e o humor característicos dos camponeses estudados por Darnton. O que se produz é uma sensação de assombro, um despertar.

Caso uma experiência de ser brasileiro possa ser comparada não a um gigante, e sim a uma bela adormecida, talvez o lugar mais propício para fazê-la despertar seja a paisagem do Buraco dos Capetas. Lá, não seria nenhum príncipe de fortuna trajado no equipamento deslumbrante que faria acordá-la. Seria, em vez dele, alguém com jeito de gente sertaneja morando numa grota, na beira de uma cidade do interior paulista. Lá, a arte de fazer despertar evoca o estilo do cozinheiro da fábula benjaminiana. Ao menos, era assim que Anaoj acordava seu filho para ir à escola: "Acorda, peste! Vai levar um tapa no ouvido se não levantar! Vai, vagabunda! Isso é hora de ficar dormindo?!" (20 de julho de 1983).

\section{Notas}

1 Professor titular do Departamento de Antropologia e coordenador do Núcleo de Antropologia, Performance e Drama (Napedra) do Programa de Pós-Graduação em Antropologia Social da USP. Agradeço à Fundação de Amparo à Pesquisa do Estado de São Paulo (Fapesp) e ao Conselho Nacional de Desenvolvimento Científico e Tecnológico ( $\mathrm{CNPq}$ ) por apoios recebidos para o desenvolvimento desta pesquisa.

2 Ao nascer de mãe índia, Macunaíma, "o herói sem nenhum caráter", era "preto retinto". Em viagem a São Paulo, ao sair de um banho de rio, ele vira "branco louro e de olhos azuizinhos" (Andrade, 1979, p. 9). "A água lavara o pretume dele. E ninguém não seria capaz mais de indicar nele um filho da tribo retinta dos Tapanhumas" (Andrade, 1979, p. 48).

3 Victor Turner discute performance como expressão de experiência que desperta um modo subjuntivo de situar-se em relação ao mundo (Turner, 1982, 1987).

4 Os nomes próprios que constam do texto podem ser considerados como ficções literárias do pesquisador. Essa observação também é válida para o nome "Jardim das Flores". O termo "Buraco dos Capetas" assim como o nome "João Branco" não deixam de ser ficções reais, nascidas da poesia dos moradores.

5 Um detalhe: tal como a sensação de punctum, sobre a qual fala Roland Barthes (1984, p. 46-47). A experiência evoca uma das imagens ausentes. Era ele - esse índio - que partia, ou ainda "parte da cena, como uma flecha, e vem me transpassar". Trata-se de um elemento do acaso, da natureza do imprevisível. Algo ali, diria Barthes, me fere ou mortifica: um detalhe me punge.

\section{ILHA}

volume 11 - número 1 
6 A "fábula das três raças", que ganha corpo em escritos como os de Gilberto Freyre (1933) e de Darcy Ribeiro (1997), é analisada criticamente por Roberto Da Matta (1987).

7 Se o nome "Jardim das Flores" surge do imaginário do pesquisador, ele não deixa de tomar o lugar de outro nome, igualmente idílico, mas também real, que brota da poesia popular.

8 Esta passagem se encontra no livro de Colin Turnbull (1962).

\section{Referências}

ANDRADE, Mário de. Macunaíma: o herói sem nenhum caráter. São Paulo: Livraria Martins, 1979.

BAKHTIN, Mikhail. A cultura popular na Idade Média e no Renascimento. São Paulo: Hucitec; Brasília: Ed. UnB, 1993.

BARTHES, Roland. A câmara clara. Tradução de J. C. Guimarães. Rio de Janeiro: Nova Fronteira, 1984.

BENJAMIN, Walter. The Origin of German Tragic Drama. Introd. George Steiner and translated by John Osborne. London/New York: Verso, 1992.

BUCK-MORSS, Susan. The Dialectics of Seeing: Walter Benjamin and the Arcades Project. Cambridge, Massachusetts London, England: MIT Press, 1991.

DA MATTA, Roberto. Digressão: a fábula das três raças, ou o problema do racismo à brasileira. In: - Relativizando: uma introdução à antropologia social. Rio de Janeiro: Rocco, 1987. p. 58-85.

DARNTON, Robert. Histórias que os camponeses contam: o significado de Mamãe Ganso. In: . O grande massacre de gatos. Rio de Janeiro: Graal, 1988. p. 21-92.

FANON, Frantz. Pele negra, máscaras brancas. Salvador, Bahia: Ed. UFBA, 2008.

FREYRE, Gilberto. Casa-grande e senzala. Rio de Janeiro: José Olympio, 1933.

MAUSS, Marcel. Uma categoria do espírito humano: a noção de pessoa, a de "eu". In: . Sociologia e antropologia. São Paulo: Cosac \& Naify, 2003. p. 367-398.

RIBEIRO, Darcy. O povo brasileiro. São Paulo: Companhia das Letras, 1997.

SCHECHNER, Richard. Between Theater and Anthropology. Philadelphia: University of Pennsylvania Press, 1985.

TURNBULL, Colin. The Forest People. New York: Touchstone Book, 1962.

\section{ILHA}


John Cowart Dawsey

TURNER, Victor. From Ritual do Theatre: The Human Seriousness of Play. New York: PAJ Publications, 1982.

. The Anthropology of Performance. New York: PAJ Publications, 1987.

Recebido em: 12/10/2010

Aceite em: 12/11/2010

ILHA

volume 11 - número 1 